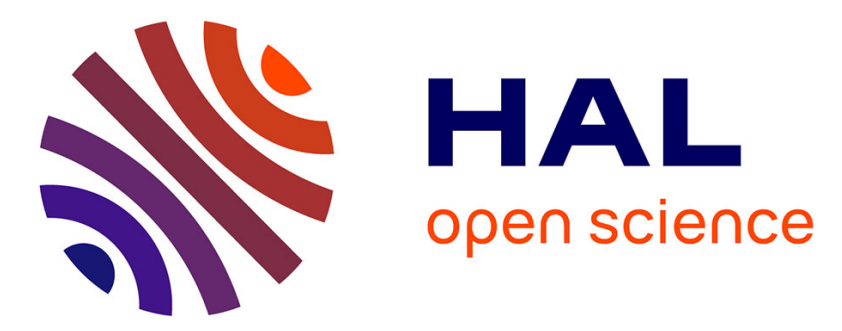

\title{
A global approach of the mechanism involved in the biosynthesis of gold colloids using micro-algae
}

Si Amar Dahoumane, Claude Yéprémian, Chakib Djédiat, Alain Couté, Fernand Fiévet, Thibaud Coradin, Roberta Brayner

\section{- To cite this version:}

Si Amar Dahoumane, Claude Yéprémian, Chakib Djédiat, Alain Couté, Fernand Fiévet, et al.. A global approach of the mechanism involved in the biosynthesis of gold colloids using micro-algae. Journal of Nanoparticle Research, 2014, 16 (10), pp.2607. 10.1007/s11051-014-2607-8 . hal-01139047

\section{HAL Id: hal-01139047 \\ https://hal.sorbonne-universite.fr/hal-01139047}

Submitted on 3 Apr 2015

HAL is a multi-disciplinary open access archive for the deposit and dissemination of scientific research documents, whether they are published or not. The documents may come from teaching and research institutions in France or abroad, or from public or private research centers.
L'archive ouverte pluridisciplinaire HAL, est destinée au dépôt et à la diffusion de documents scientifiques de niveau recherche, publiés ou non, émanant des établissements d'enseignement et de recherche français ou étrangers, des laboratoires publics ou privés. 
A Global Approach of the Mechanism Involved in the Biosynthesis of Gold Colloids using Micro-algae

Si Amar Dahoumane, ${ }^{1}$ Claude Yéprémian, ${ }^{2}$ Chakib Djédiat, ${ }^{2}$ Alain Couté, ${ }^{2}$ Fernand Fiévet, ${ }^{1}$ Thibaud Coradin, ${ }^{3, *}$ Roberta Brayner ${ }^{1, *}$

${ }^{1}$ Interfaces, Traitements, Organisation et Dynamique des Systèmes (ITODYS), UMR 7086, CNRS, Sorbonne Paris Cité, Université Paris Diderot, 15 Rue Jean de Baïf, 75205 Paris Cedex 13, France

${ }^{2}$ Département RDDM, FRE 3206, USM 505, Muséum National d'Histoire Naturelle, 57 Rue Cuvier, 75005 Paris, France

${ }^{3}$ CNRS, Chimie de la Matière Condensée de Paris (LCMCP), Collège de France, UPMC Université Paris 06, 11 Place Marcellin Berthelot, 75005 Paris, France

* Corresponding authors:

Dr. R. Brayner: roberta.brayner@univ-paris-diderot.fr

Dr. T. Coradin: thibaud.coradin@upmc.fr 


\section{Abstract}

The use of micro-algae for the production of noble metal nanoparticles has drawn much attention recently. This paper aims to address some questions raised by our earlier publications and some recent reports from other groups, among which the biological pathways involved in the bioreduction of noble metal cations into nanoparticles and the design of stable colloids. TEM micrographs, taken at the early stage of contact between cells and salt solutions, show undoubtedly that the biomineralization process occurs within the thylakoidal membranes, which are the organelles responsible for photosynthesis. We strongly believe that the available enzymatic machinery (respiratory enzymes and their cofactors) are the key-molecules that allow such reduction, promoting therefore the formation of nanoparticles. In addition, by comparing the characteristics of gold colloids made by polysaccharides producing and non-producing micro-algae strains, we demonstrate that the stability of those colloids is ensured predominantly by those biopolymers. These macrobiomolecules control partly the size and the shape of NPs.

Keywords: Gold Nanoparticles, Gold Colloids, Biosynthesis, Thylakoids, NP stabilization, Polysaccharides, Micro-algae. 


\section{Introduction}

Scientists have been exploiting the exceptional diversity of micro-organisms, such as bacteria, yeast, fungi and micro-algae, to fabricate a wide variety of functional nanomaterials. ${ }^{1,2}$ For instance, cellcontaining bacteria cultures or their supernatants can promote the synthesis of noble metal nanoparticles (NPs), such as gold $(\mathrm{Au}),^{3-8}$ silver $(\mathrm{Ag}){ }^{9-11}$ palladium $(\mathrm{Pd})^{12}$ and platinum $(\mathrm{Pt}){ }^{13,14}$ or bimetallic Ag-Au nanoparticles. ${ }^{15}$ Bacteria can also promote the biosynthesis of a variety of metal oxides nano-objects, such as magnetite $\left(\mathrm{Fe}_{3} \mathrm{O}_{4}\right),{ }^{16}$ greigite $\left(\mathrm{Fe}_{3} \mathrm{~S}_{4}\right),{ }^{17}$ titania $\left(\mathrm{TiO}_{2}\right)^{18}$ and zinc oxide $(\mathrm{ZnO}) .{ }^{19}$ The same cultures can be involved in the bioproduction of different chalcogenides, such as cadmium sulfide (CdS) ${ }^{20-22}$ lead sulfide $(\mathrm{PbS}),{ }^{23}$ elemental selenium nanospheres and zinc selenide $(\mathrm{ZnSe}){ }^{24}$ and photoactive arsenic sulfide nanotubes (AsS). ${ }^{25}$ Additionally, different fungus and yeast strains can be used to initiate the biosynthesis of noble metal nanoparticles, such as gold ${ }^{26-28}$ and silver, ${ }^{29-31}$ different oxide nano-objects, such as magnetite, ${ }^{32}$ zirconia ( $\left.\mathrm{ZrO}\right),{ }^{33}$ barium titanate $\left(\mathrm{BaTiO}_{3}\right),{ }^{34}$ antimony trioxide $\left(\mathrm{Sb}_{2} \mathrm{O}_{3}\right),{ }^{35}$ titania and silica, ${ }^{36}$ and chalcogenide nanomaterials, such as $\mathrm{CdS}^{22,37-40}$ and $\mathrm{CdSe}^{41}$

Similarly, there have been several reports dealing with the use of algal resources for the biosynthesis of noble metal nanomaterials. For instance, biomass extracted from seaweed, ${ }^{42-46}$ microalgae $^{46-48}$ and cyanobacteria ${ }^{49,50}$ has been tested successfully in the bioreduction of gold cations into their metallic nanoscaled-counterparts. Cyanobacterial biomasses can also be used to carry out the bioproduction of $\mathrm{Ag}, \mathrm{Pt}$ and $\mathrm{Pd}$ nanoparticles. ${ }^{51-53}$ Brayner's group was the first team to ever show the ability of living cultures of cyanobacteria to perform the biosynthesis of stable colloids made of $\mathrm{Ag}, \mathrm{Au}, \mathrm{Pt}$ and $\mathrm{Pd}$ nanoparticles. ${ }^{54}$ Since then, the reduction of gold cations into gold nanoparticles by living diatoms ${ }^{55}$ and Chlorella vulgaris cultures $^{56}$ has been reported. Dahoumane et al. have demonstrated the ability of several strains of fresh-water green micro-algae living cultures to produce very stable gold colloids. ${ }^{57}$ The introduction of chloro-auric acid solutions into the cultures triggers the biosorption by the cells of these cations, followed by their reduction into metallic gold, leading, therefore, to the subsequent intracellular formation of the NPs. Finally these NPs are released into culture media. In other words, each cell acts as a microbioreactor and the whole culture as a bioreactor. Importantly, Sicard et al. have demonstrated that micro-algae keep their reductive ability when encapsulated within sol-gel based materials. ${ }^{58}$ Moreover, Dahoumane et al. have shown that micro-algae can adapt to the toxicity of gold cations and handle larger amounts of these cations. ${ }^{59}$ More recently, Dahoumane et al. have used living cultures of Chlamydomonas reinhardtii, a unicellular fresh-water green micro-alga, to perform the synthesis of bimetallic $\mathrm{Ag}-\mathrm{Au}$ alloy colloids with a very good stoichiometrical control over NPs composition comparable to those chemically made. ${ }^{60}$

A schematic mechanism was proposed to account for the bioformation of gold colloids after the introduction of gold cations into living micro-algae cultures. ${ }^{57}$ It was demonstrated, using optical microscopy, that the NP synthesis is intracellular, and suggested, using TEM imaging, that this process occurs within the thylakoids, which constitutes the $1^{\text {st }}$ level of NP size and shape control. This study also brought to mind the potential role played by respiratory enzymes and their cofactors in the reduction of gold cations into metallic counterparts, and the role of cell-produced polysaccharides (PS) in NP stabilization. PS capping the NPs constitutes the $2^{\text {nd }}$ level of NP size and shape control by preventing NP growth or coalescence. Recently, Shabnam et al. have used thylakoid suspensions, isolated from aquatic and terrestrial plants, to carry out the synthesis of Au-NPs, 
starting from $\mathrm{Au}$ (III) complexes. They have evidenced that these organelles have the ability to reduce $\mathrm{Au}^{3+}$ and generate Au-NPs through a light-dependent process. ${ }^{61}$

We report in this paper, first, on the localization of the first produced Au-NPs within the cells, using TEM pictures, after the introduction of chloro-auric acid solution into a living culture of Cosmarium impressulum (Ci), a unicellular fresh water green micro-alga. Second, wishing to learn more about the role played by the PS in the control of NP size and shape, and colloid stability over time, we compare exhaustively the characteristics of NPs produced by two different micro-algal strains, Kirshneriella lunaris $(K I)$, a unicellular moon-shaped fresh water green micro-alga known to produce PS, and a non-producing one, Euglena gracilis (EgM). Third, we demonstrate the ability of PS, harvested from an old $\mathrm{Ci}$ culture, to stabilize chemically generated Au-NPs. Finally, we provide with the whole picture of the biological process underlying gold colloid design.

\section{Materials and methods}

\section{Micro-algal strains description and culture}

Three photosynthetic organisms with distinct structural or physiological features were selected: Cosmarium impressulum ( $\mathrm{C}$ ) and Kirchneriella lunaris (KI), two planktonic single-celled eukaryotic green algae coated with EPS; and Euglena gracilis (EgM), a single-celled eukaryotic euglenoid without EPS. Ci (ALCP \#15), KI (ALCP\#92) and EgM (ALCP \#217) came from MNHN Culture Collection. Ci and KI were grown in 250-mL Erlenmeyer flasks, in sterile Bold's basal (BB) medium whose $\mathrm{pH}$ was adjusted to 7 using $1 \mathrm{M} \mathrm{NaOH}$ solution and buffered with $3.5 \mathrm{mM}$ phosphate buffer at a controlled temperature of $20.0 \pm 1.0{ }^{\circ} \mathrm{C}$ and luminosity $\left(30-60 \mathrm{Imol} \mathrm{m}^{-2} \mathrm{~s}^{-1} \mathrm{PPF}\right)$ and under ambient $\mathrm{CO}_{2}$ conditions. EgM was grown in 250-mL Erlenmeyer flasks, in Mineral (M) medium at a controlled temperature of $20.0 \pm 1.0^{\circ} \mathrm{C}$ and luminosity $\left(70-100 \mathrm{Imol} \mathrm{m}^{-2} \mathrm{~s}^{-1} \mathrm{PPF}\right)$ under ambient $\mathrm{CO}_{2}$ conditions. The $\mathrm{pH}$ of the medium was adjusted to 3.6 using $1 \mathrm{M} \mathrm{HCl}$ solution.

Before addition of gold salts, the culture was transferred (10\% (v/v) of inoculum) into the culture medium, and grown for 2 weeks. $\mathrm{Ci}$ culture was used to determine the organelle responsible of the gold cation reduction into metallic gold, leading hence to the formation of GNPs. To do so, $10.0 \mathrm{~mL}$ of $\mathrm{HAuCl}_{4}$ aqueous solution, at an initial concentration of $2.5 \times 10^{-3} \mathrm{M}$, were introduced into $\mathrm{Ci}$ culture to obtain a final concentration of $2.5 \times 10^{-4} \mathrm{M}$. One hour later, an amount of $\mathrm{Ci}$ cells were fixed and imaged using TEM, following the procedure described below.

To study the role played by PS in the stabilization of gold colloids, two micro-algal species were chosen: $K I$ which is known to be coated in a PS layer, and $E g \mathrm{M}$ which does not produce any PS. To each of these cultures, $10.0 \mathrm{~mL}$ of $\mathrm{HAuCl}_{4}$ aqueous solution, at an initial concentration of $1.0 \times 10^{-3}$ $\mathrm{M}$, were added to obtain a final concentration of $1.0 \times 10^{-4} \mathrm{M}$.

\section{PS extraction}

PS were isolated from an aged $\mathrm{Ci}$ culture of more than 7 months, of an initial volume of $200 \mathrm{~mL}$, which appeared viscous and gelatinous, following a procedure adapted from Bertocchi et al. ${ }^{62} \mathrm{In}$ order to dissolve the PS, the cell biomass was mixed with $\mathrm{H}_{2} \mathrm{O}$ and boiled for one hour, and then centrifuged. Three volumes of ethanol were added to the isolated supernatant containing PS, which 
was then purified using a dialysis membrane, and finally lyophilized to harvest the PS. The yield was $25 \mathrm{mg}$ for $100 \mathrm{~mL}$ of the initial cell culture.

\section{Stability of gold colloids}

The evolution of surface plasmon resonance (SPR) band intensity of the obtained colloids, after the addition of gold salt solutions into $K I$ and $E g M$ cultures, was monitored using a Cary $5 \mathrm{E}$ spectrophotometer. $\sim 2 \mathrm{~mL}$ of the colloids were scanned between 400 and $800 \mathrm{~nm}$, at different dates.

\section{Chlorophyll a measurements}

The chlorophyll $a$ was extracted from $1 \mathrm{~mL}$ of unicellular algal culture in $9 \mathrm{~mL}$ of acetone, according to a protocol published by Ninfa et al..$^{63}$ After 1 min of vortex, the mixture was heated at $37^{\circ} \mathrm{C}$ for 3 min followed by centrifugation. The evolution of chlorophyll $a$ band, centered at $663 \mathrm{~nm}$, was followed by UV-Vis spectroscopy, using a Cary 5E spectrophotometer.

\section{Cell preparation for TEM observation}

Biomass transmission electron microscopy (TEM) imaging was performed with a Hitachi $\mathrm{H}-700$ operating at $75 \mathrm{kV}$ equipped with a Hamatsu camera. To determine where the first GNPs appear within the cells, $\mathrm{Ci}$ cells were fixed, one hour $(\mathrm{h}+1)$ after their contact with gold cations, with a mixture containing $2.5 \%$ of glutaraldehyde, $1.0 \%$ of picric acid in a phosphate Sörensen Buffer (0.1 $\mathrm{M}, \mathrm{pH}$ 7.4). Dehydration was then achieved in a series of ethanol baths, and the samples were processed for flat embedding in Spurr resin. Ultrathin sections were made using a Reicherd E Young Ultracut ultramicrotome (Leica). Sections were contrasted with ethanolic uranyl acetate before visualization.

\section{Photonics}

Optical microscopy was performed using Primo Star optical microscopy from Zeiss.

\section{Results and Discussion}

\section{TEM localization of Au-NPs place of birth}

To determine with certainty the place of birth of the very first Au-NPs within the cells, we proceeded to the fixation of $\mathrm{Ci}$ cells an hour $(\mathrm{h}+1)$ after chloro-auric acid solution had been introduced into the culture to get a final concentration of $2.5 \times 10^{-4} \mathrm{M}$. Figure 1 displays an optical image of a whole $\mathrm{Ci}$ cell (a-1) and culture (a-2) before the addition of $A u(I I I)$ solution. Five days (D+5) after the introduction of the above mentioned solution into the culture, both cells (b-1) and culture (b-2) turned from green to purple evidencing respectively the intracellular reduction of gold cations into metallic gold, the subsequent formation of Au-NPs, and the release of these latter into culture media, leading to the design of stable gold colloids. Figure (c) represents a micrograph of a whole $\mathrm{Ci}$ cell fixed one hour $(h+1)$ after the gold salts solution were added to the culture. One can distinguish clearly all cell compartments, in the two lobes or hemistomates, separated by the isthmus. From outside to inside, we can easily recognize the cell wall (CW), the plasmic membrane (PM) and the periplasmic space between $\mathrm{CW}$ and PM, several vacuoles $(\mathrm{V})$, the nucleus $(\mathrm{N})$ located in the central 
region of the cell, and its nuclear membrane (NM), several thylakoids (Th) some of which are surrounding the pyrenoid $(P)$. This latter is known to be the cell stock organelle. One can also notice black spots which may be dust grains or artefacts due to sample preparation for TEM imaging.

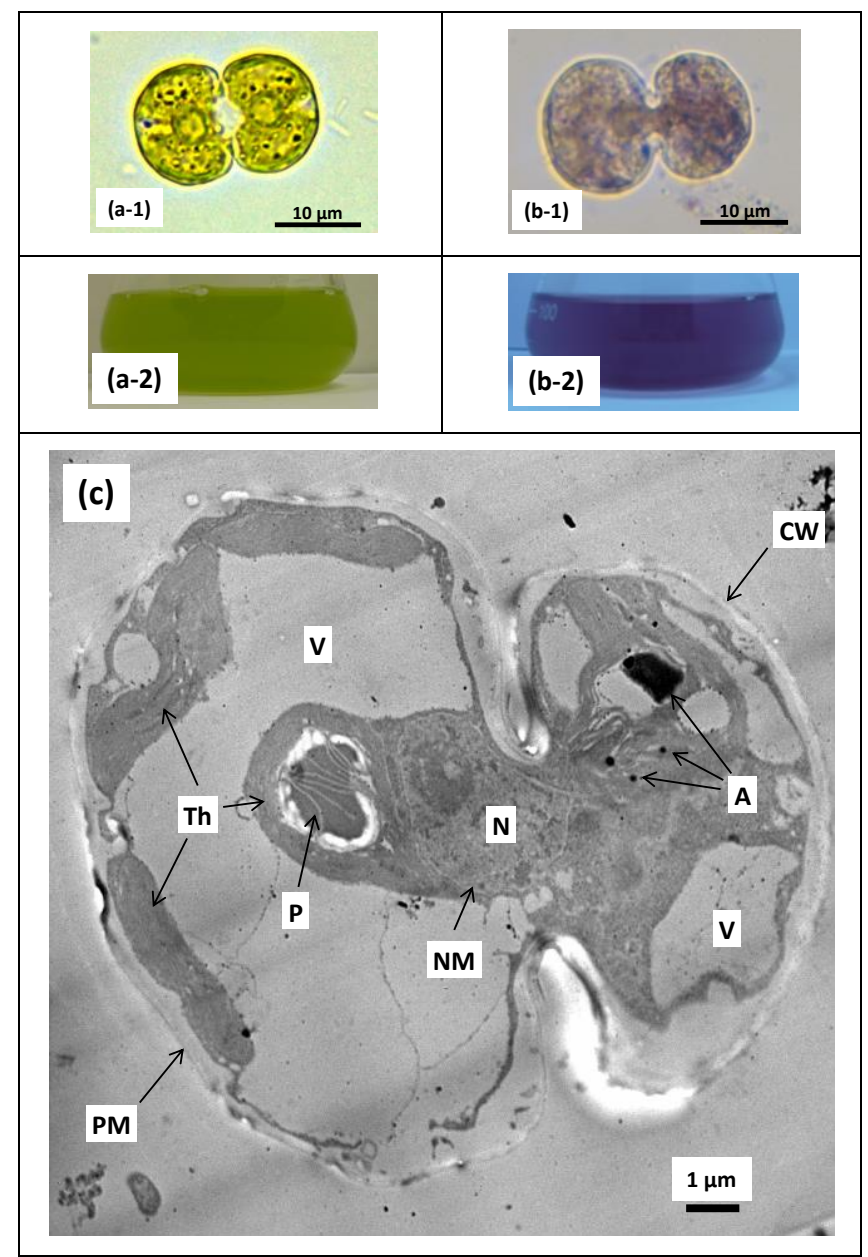

Figure 1: Optical image of a single cell of Cosmarium impressulum, $\mathrm{Ci}(\mathrm{a}-1)$, and a digital picture of $\mathrm{Ci}$ culture (a-2) before addition of $\mathrm{HAuCl}_{4}$ solution. (b-1) displays an optical image of a single $\mathrm{Ci}$ cell, and (b-2) a digital image of $\mathrm{Ci}$ culture, five days (D+5) after $\mathrm{HAuCl}_{4}$ solution introduction. (c) a micrograph of a whole cell of $\mathrm{Ci}$ taken one hour $(\mathrm{h}+1)$ after $\mathrm{HAuCl}_{4}$ solution introduction.

Same sample TEM pictures at a higher magnification (Fig. 2-a and 2-b), taken at $h+1$, evidence the presence of the NPs, in their vast majority within the thylakoids or in their vicinity. A few of them are visible at the intracellular membranes and cytoplasmic membrane. Some of these nano-objects are lined up along the thylakoidal membranes. All these Au-NPs are uniformly sphere-shaped. It seems that the intracellular growth of NPs favors, exclusively, the round-shaped morphology. However, their size varies from a few to several nanometers. The smallest NPs are hardly recognizable while the biggest are of tens of $\mathrm{nm}$ in diameter. This discrepancy in size may be due to the ongoing process of NP formation: the oldest ones having underwent growth and gained in size are outer NPs that are most likely to be in close contact each other and then to coalesce than the inner ones, leading therefore to bigger NPs. 


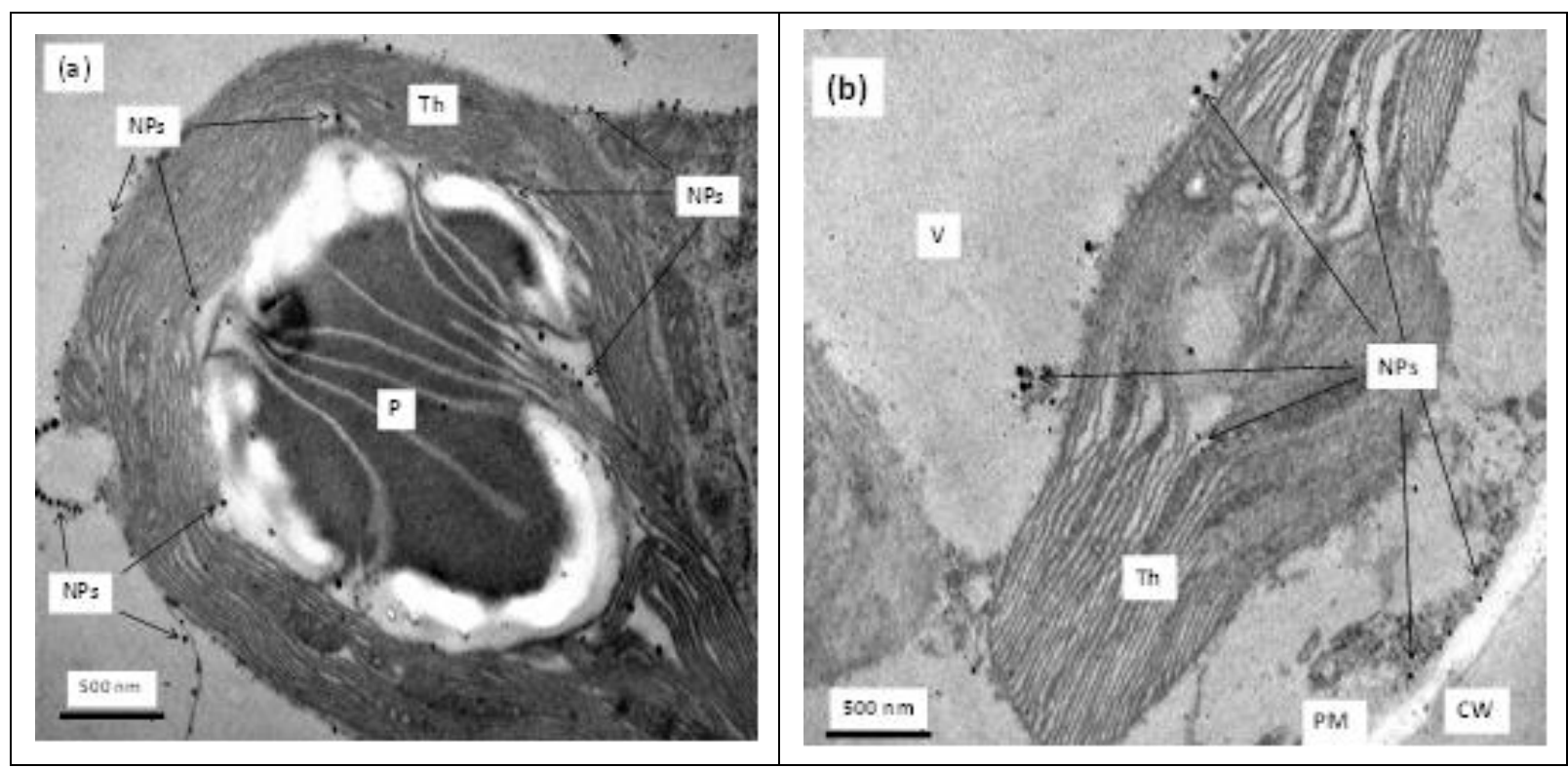

Figure 2: TEM micrographs at higher magnification of (a) thylakoids surrounding the pyrenoid, and (b) a thylakoid located close to the cell wall.

The ultrastructure of a thylakoid confirmed the above-mentioned findings (Fig. 3). This picture depicts undoubtedly the space-repartition of Au-NPs within the chloroplasts according to size, the smaller ones found at the inner part of those organelles, in the space between the thylakoidal membranes, whereas the biggest nano-objects are located at the outer space and in the vicinity of these photosynthesis responsible organelles. This result corroborates that the reduction of gold cations into the metallic gold, that is to say the biosynthesis of Au-NPs, occurs within the chloroplast, and the structure of the thylakoids and the space between the thylakoidal membranes play a key role in the control of NP dimensions.

This is the first time that the role played by thylakoids during the bioformation of noble metal NPs is demonstrated. This corroborates the studies done by Zhang et al. ${ }^{64}$ and Shabnam et al. ${ }^{61}$ which showed that isolated chloroplasts, the photosynthetic organelles of algae and plants, could be used to synthesize nanomaterials. This also confirms what we stated in our earlier publications by suggesting that the thylakoids are the place of birth of Au-NPs, after the reduction of gold cations into metallic gold. ${ }^{54,57}$ 


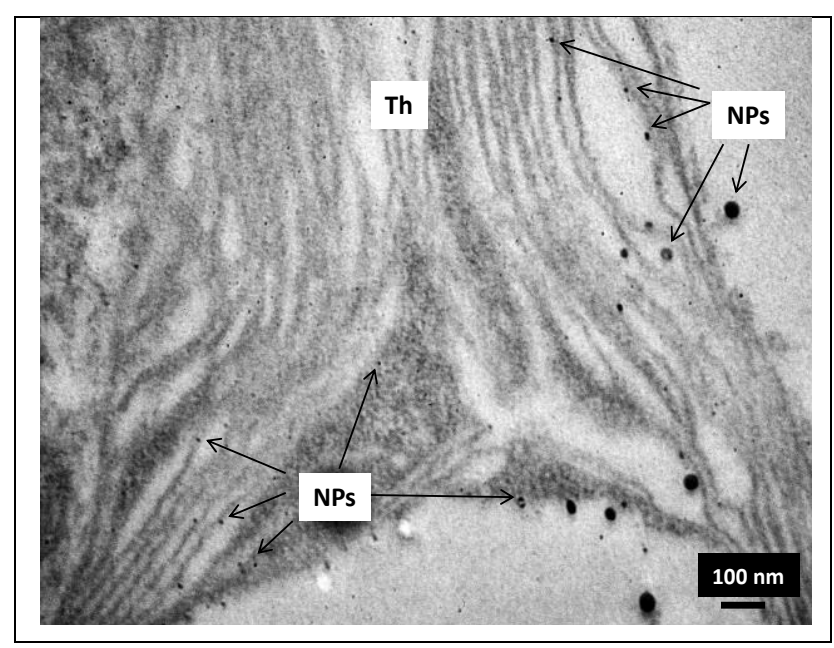

Figure 3: Ultrastructure of a region of thylakoid showing Au-NPs of different sizes.

\section{Role of EPS in the stabilization of Au-NPs, and the control of their size and shape}

In the previous section, we have demonstrated that the reduction of $A u(I I I)$ into $A u(0)$ occurs within the cells, more precisely within the thylakoidal membranes, leading therefore to the bioformation of Au-NPs. This intracellular synthesis constitutes the first level of NP size and shape control. In the following section, we explore the influence of the presence of PS or not on gold colloid characteristics, such as the shape and the size of the NPs, and colloid stability over time. To do so, we chose two different unicellular algal strains, Kirchneriella lunaris, Kl, known to produce extracellular matrices, ECM or PS, and Euglena gracilis, EgM, not known to produce such biopolymers. We added the same amount of $\mathrm{HAuCl}_{4}$ solution, at a final concentration of $10^{-4} \mathrm{M}$, to both cultures.

In the case of EgM (Fig.4 a-1), one day (D+1) after the cells were brought into contact with $\mathrm{Au}(\mathrm{III})$, the culture turned straight away from green $(D+0)$ to dark purple which confirms a rapid gold cation reduction into metallic gold and the release of the as-produced Au-NPs into culture media (CM). However, this color became lighter with time as displayed by the picture taken almost two weeks later $(D+13)$. This colloid was not stable and the Au-NPs eventually started to sediment. On the other hand, $K I$ culture (Fig. 4 b-1) exhibited a quite different behavior. Initially green ( $D+0)$, this culture turned into light red $(D+1)$ and, as the process of NP release continued gradually, this color became darker with time $(D+14)$.

The trend in color change, due to NP intracellular biosynthesis and release into culture media, was monitored, for both cultures, using UV-Vis spectroscopy. Both species displayed the characteristic surface plasmon resonance (SPR) band of spheric Au-NPs, located at $\sim 540$ and $\sim 520 \mathrm{~nm}$ for EgM (Fig. 4 a-2) and $K I$ (Fig. 4 b-2) cultures respectively. However, the intensity of the SPR band decreased with time for $E g M$ culture while it increased for the $K l$ one. This trend was confirmed by plotting the maximum of SPR band intensity vs. time, $A b s_{\max }=f(t)$. In the case of $E g M(F i g .4$ a-3), the NP release reached its maximum one day after the cells have been brought into contact with chloro-auric acid solution. After that time, the intensity tended to drop down quasi-linearly. On the contrary, the SPR intensity of $\mathrm{Kl}$ sample (Fig. $4 \mathrm{~b}-3$ ) increases gradually with time and plateaus approximately nine days after the addition of $\mathrm{HAuCl}_{4}$ to the culture. It is important to notice that, for both samples, there is a good agreement between the evolution of the macroscopic aspect and UV-Vis measurements. 


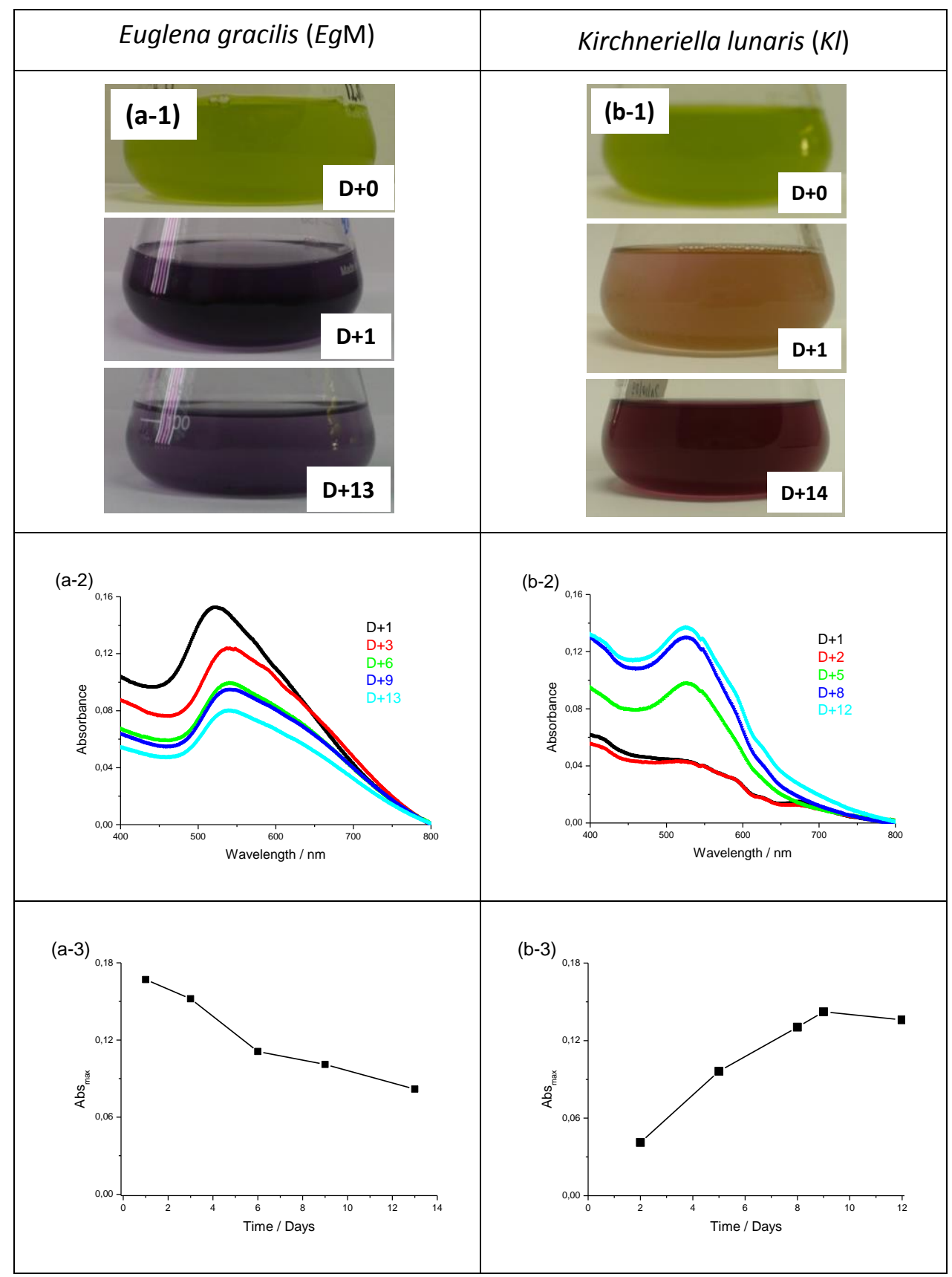

Figure 4: Evolution of the macroscopic aspect of $E g M(a-1)$ and $K I(b-1)$ cultures respectively. (a-2) and (b-2): Evolution of the SPR band for EgM and KI respectively. (a-3) and (b-3): Kinetics of NP release into culture media for $E g M$ and $K I$ respectively.

To study the size and the shape of the Au-NPs made by each strain, TEM images were performed on droplets taken from each sample. EgM sample (Fig. 5 a-1) shows three distinguishable NP populations, smaller and medium objects which seem to be spherical and imprisoned within an organic network, and bigger round-shaped objects. NPs made by $K I$ are more uniformly shaped and sized (Fig. 5 b-1). These objects appear to be all sphere shaped with a diameter of a few nanometers $(\sim 5 \mathrm{~nm})$. The presence of the organic matter in the case of $E g \mathrm{M}$, due likely to the massive cell death triggered by the toxicity of gold cations, did not prevent the NPs from aggregation and sedimentation. This cell death was confirmed by the evolution of chlorophyll $a$ intensity, monitored using UV-Vis spectroscopy measurements. For both strains (Fig. 5 a-2 and b-2), the trend was similar. 
The addition of chloro-auric acid solution led to a huge cell death. However, after a while, both species recovered and grow up significantly. It is important to notice that, in the case of $K I$ (Fig. 5 b2 ), the use of acetone to prepare the sample for chlorophyll $a$ measurements did not alter the stability of the gold colloid. Indeed, Au-NPs remained stable and their SPR band was still visible evidencing a strong anchoring of PS into NP surfaces. This was not the case of EgM (Fig. 5 a-2). If the released organic matter from cells, most likely proteins, was involved in the capping of the NPs and the stabilization of the colloids, one would expect the same behavior for both strains, the PS producing species and the non-producing one. This was not the case. It is why we believe those biopolymers are the predominantly macrobiomolecules involved in the stabilization of the colloids by avoiding the aggregation, the growth and the sedimentation of the NPs.

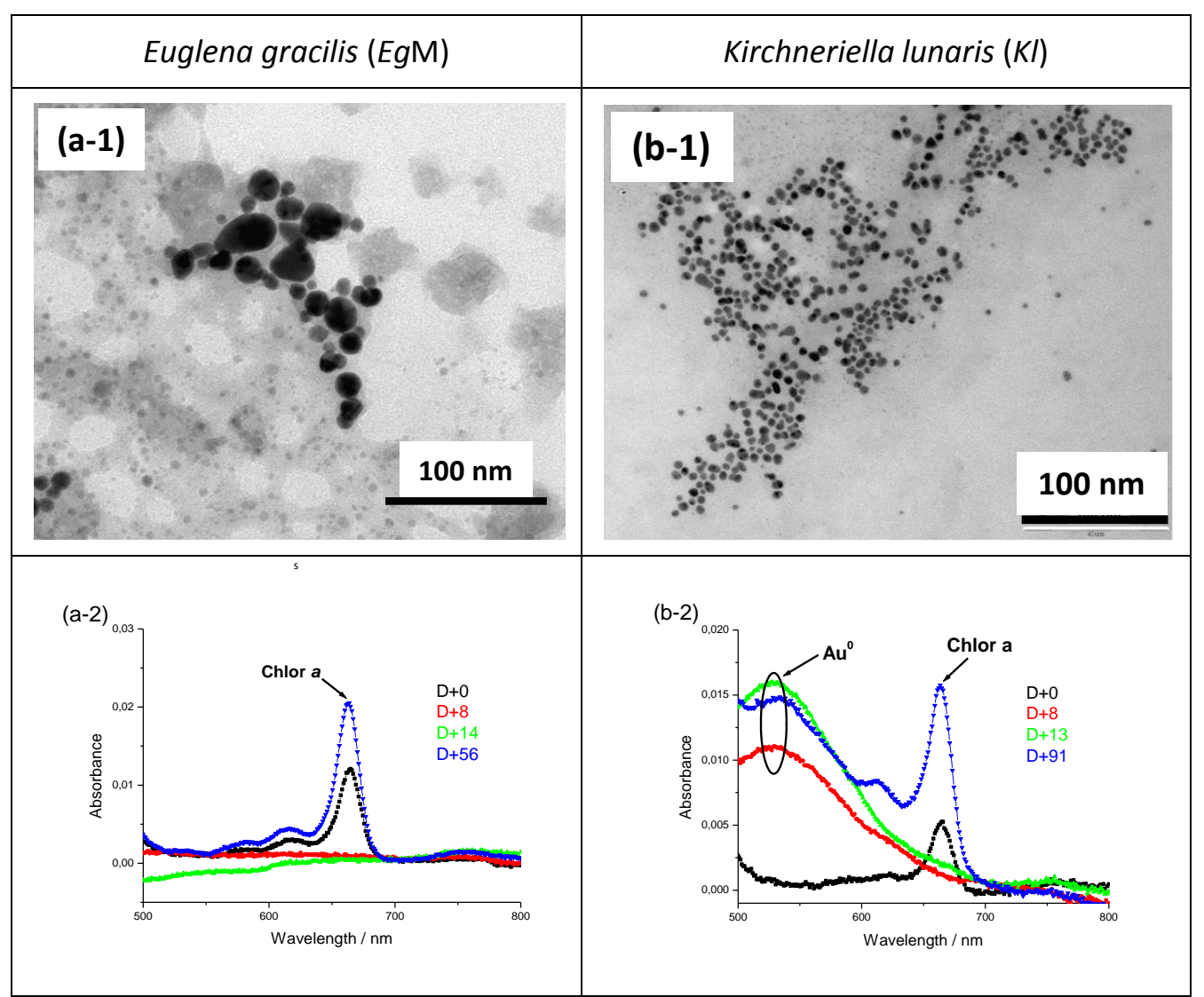

Figure 5: Micrographs of Au-NPs made by $\operatorname{EgM}(a-1)$ and $K I(b-1)$; and evolution of the cell viability of $\operatorname{EgM}(\mathrm{a}-2)$ and $K I(\mathrm{~b}-2)$.

To investigate the role played by PS in the stabilization of gold colloids, we extracted these biopolymers from a very old $\mathrm{Ci}$ culture. This strain is known to produce huge amounts of PS. Seven months after its launch with an initial volume of $200 \mathrm{~mL}$, the volume shrunk and the cells formed a green and very gelatinous mass. This pasty aspect provides an idea of its richness of PS. $50 \mathrm{mg}$ of PS were collected making the yield at $0.25 \mathrm{mg} / \mathrm{mL}$. After that, we compared the stability of chemicallymade Au-NPs. In this experiment, two glass vials were filled with $10 \mathrm{~mL}$ of BB culture medium containing $\mathrm{Au}$ (III) at a final concentration of $10^{-4} \mathrm{M}$. To the first vial (Fig. 6 a-1) were added PS at a mass concentration of $0.25 \mathrm{mg} / \mathrm{mL}$ while the second one was kept (Fig. 6 b-1) PS free. The addition of 
$20 \mu \mathrm{L}$ of hydrazine $\left(10^{-4} \mathrm{M}\right)$ under a vigorous magnetic stirring to each vial triggered a color change for both vials, the first one containing PS became purplish (Fig. 6 a-2) while the second (Fig. 6 b-2), PSfree, became blue. The color change is the evidence of Au-NPs apparition in both vials. However, one day $(D+1)$ after the magnetic stirring had been turned off, no remarkable change was noticed for the first vial (Fig. 6 a-3) whereas the second vial became transparent (Fig. 6 b-3) due to Au-NPs sedimentation with the formation of a visible layer at the bottom of the vial and a deposit on the upper part of the glass wall, at the interface between the liquid and the air. This is another proof that the stabilization of micro-algal-made Au-NPs is made possible by the presence of the available PS within and/or at the surface of the cells.

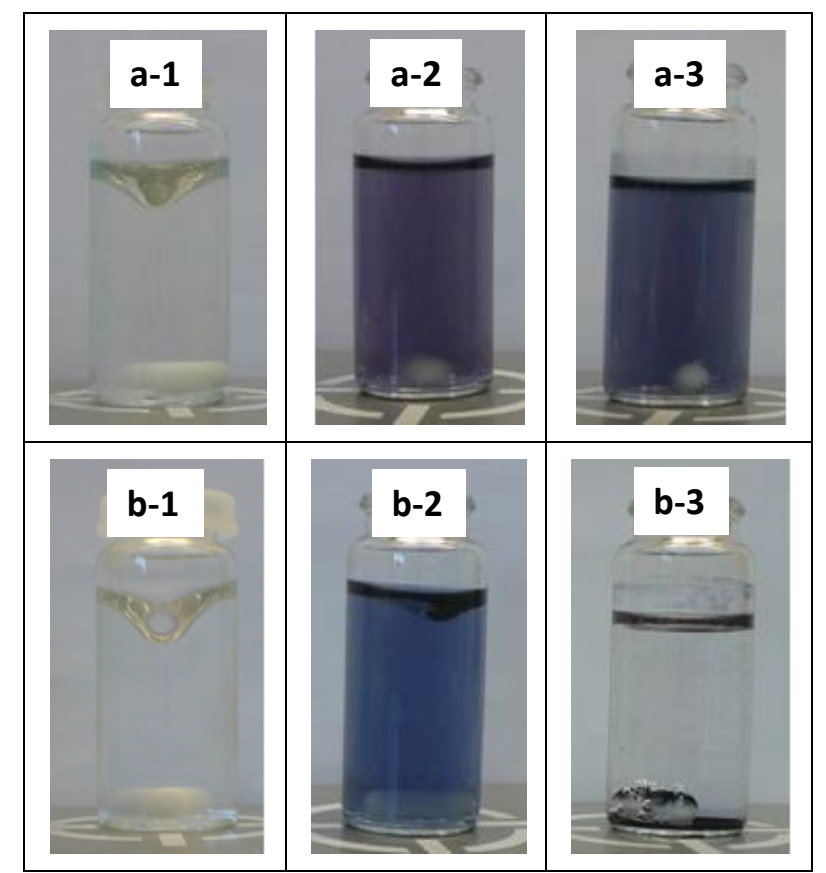

Figure 6: Digital images demonstrating the role played by micro-algal extracted PS in the stability of gold colloids. (a-1): $\mathrm{HAuCl}_{4}$ solution at $10^{-4} \mathrm{M}$ containing PS at $0.25 \mathrm{mg} / \mathrm{mL}$; (a-2): a few minutes after addition of hydrazine under vigorous stirring; and (a-3) one day later $(D+1)$ after the stirring had been turned off. (b-1): $\mathrm{HAuCl}_{4}$ solution at $10^{-4} \mathrm{M}$ without PS; (b-2): a few minutes after addition of hydrazine under vigorous stirring; and (b-3) one day later $(D+1)$ after the stirring had been turned off.

\section{Conclusion and perspectives}

This work aimed to contribute to a better understanding of the biological pathways involved in the bioformation of gold colloids after living micro-algal cultures were put into contact with $\mathrm{Au}(\mathrm{III})$ solutions by elucidating the cell organelles responsible for the reduction of such cations and the biomolecule assuring the stabilization of the colloids. Micrographs at the early stages of this contact have demonstrated that gold cations migrate into the photosynthetic organelles, i.e. chloroplasts or thylakoids, where they are reduced into their metallic counterparts, leading therefore to the production of Au-NPs. The fact that NP formation occurs within the thylakoids constitutes the first level of shape and size control. In the presence of PS in appropriate amounts, these NPs will form 
stable colloid after being released into culture media. Even if we do not exclude the contribution of the intracellular organic matter, we can claim that PS are the predominant macrobiomolecules responsible for the colloidal stability. This constitutes the second and last level of NP shape and size control by hindering their merging and their growth.

We have summarized our findings regarding the most likely mechanism of gold colloid design using living algal cultures in Figure 7: (i) Addition of $A u(I I I)$ aqueous solution into a healthy algal culture whose cells are known to produce PS; (ii) internalization of $\mathrm{Au}(\mathrm{III})$ by the cells through an osmotic process; (iii) intracellular reduction of $\mathrm{Au}(\mathrm{III})$ into $\mathrm{Au}(0)$ within the thylakoidal membranes taking profit from the available enzymatic machinery; (iv) growth of Au-NPs after the merging of Au atoms; (v) diffusion of Au-NPs from the chloroplasts into the cytoplasmic membrane and cell wall; (vi) encapsulation of Au-NPs within PS-based networks at the cell wall; (vii) release of the as-protected Au-NPs into culture media; (viii) elaboration of stable colloids.

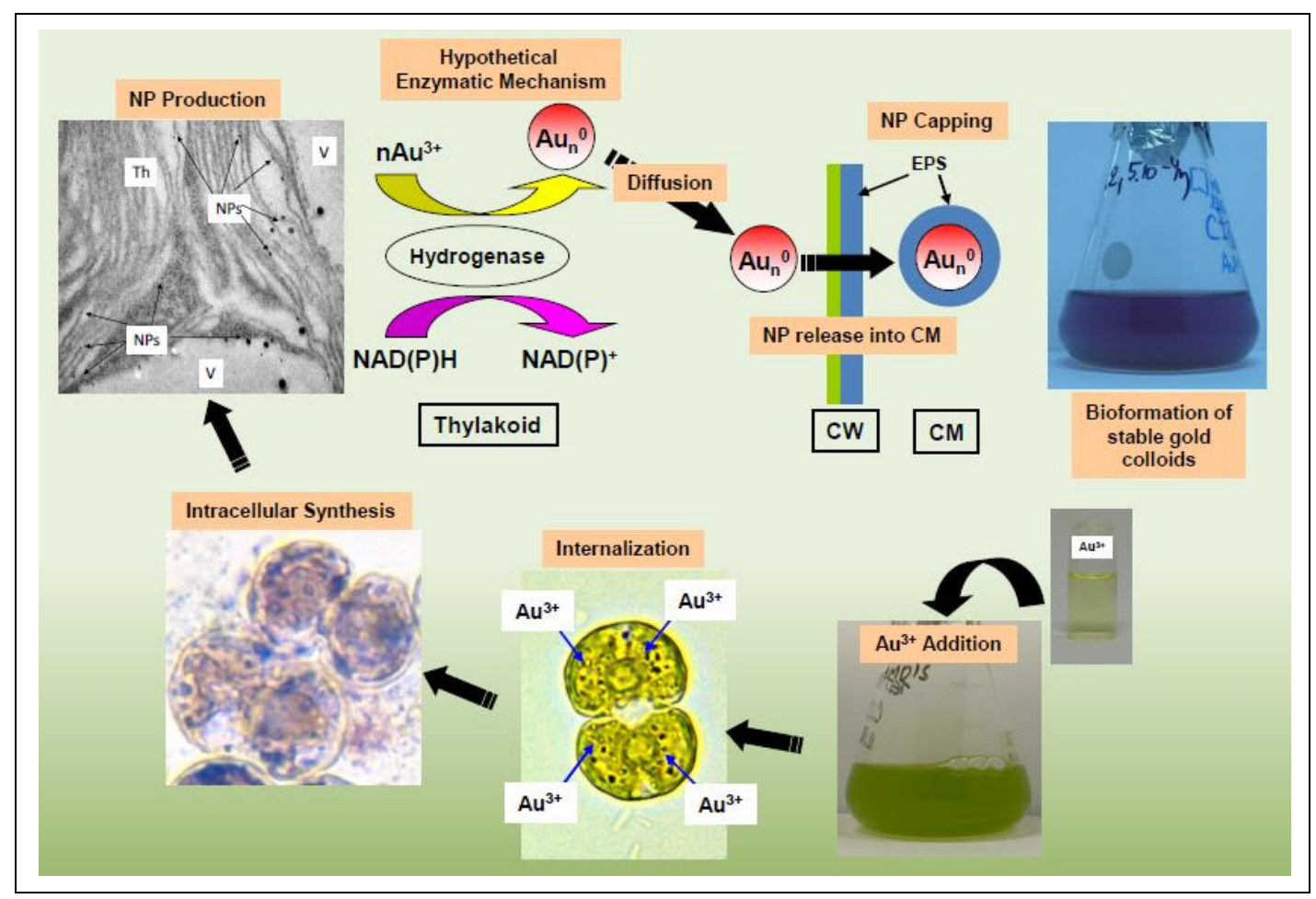

Figure 7: Global picture of the schematic mechanism involved in the bioproduction of stable gold colloids through a micro-algal mediated route.

However, several questions remain unanswered and a thorough investigation should be implemented in order to understand the following issues: (i) what incites living micro-algal cells to reduce noble metal cations into metallic entities while, in the case of iron cations for instance, the cells promote the synthesis of oxides? ${ }^{65-67}$ (ii) What explains the difference in shape and size between these nano-oxides and their noble-metal counterparts? (iii) What explains the fact that oxides NPs are kept within the cells whereas noble metal NPs are released into culture media? Is this related to any evolutionary process? (iv) What molecules and/or biomolecules are the electron donors in the case of noble metal cations reduction? We suggested in a previous paper that NADP(H) is the most likely molecule to fulfill this role as it is involved in such processes in several biochemical pathways. ${ }^{57}$ 
(v) Is this reduction process light-driven, as suggested recently? ${ }^{61}$ Or isolated chloroplasts do not behave the same way when they are parts within the cells?

\section{References}

(1) Lloyd, J. R.; Byrne, J. M.; Coker, V. S.: Biotechnological Synthesis of Functional Nanomaterials. Current opinion in biotechnology 2011, 22, 509-515.

(2) Narayanan, K. B.; Sakthivel, N.: Biological Synthesis of Metal Nanoparticles by Microbes. Advances in colloid and interface science 2010, 156, 1-13.

(3) Gericke, M.; Pinches, A.: Biological Synthesis of Metal Nanoparticles. Hydrometallurgy 2006, 83, 132-140.

(4) Deplanche, K.; Macaskie, L. E.: Biorecovery of Gold by Escherichia coli and Desulfovibrio desulfuricans. Biotechnology and bioengineering 2008, 99, 1055-1064.

(5) Kalishwaralal, K.; Deepak, V.; Ram Kumar Pandian, S.; Gurunathan, S.: Biological Synthesis of Gold Nanocubes from Bacillus licheniformis. Bioresource technology 2009, 100, 53565358.

(6) Kashefi, K.; Tor, J. M.; Nevin, K. P.; Lovley, D. R.: Reductive Precipitation of Gold by Dissimilatory Fe(III)-reducing Bacteria and Archaea. Applied and environmental microbiology 2001, 67, 3275-3279.

(7) Husseiny, M. I.; El-Aziz, M. A.; Badr, Y.; Mahmoud, M. A.: Biosynthesis of Gold Nanoparticles using Pseudomonas aeruginosa. Spectrochimica acta. Part A, Molecular and biomolecular spectroscopy 2007, 67, 1003-1006.

(8) He, S.; Zhang, Y.; Guo, Z.; Gu, N.: Biological Synthesis of Gold Nanowires Using Extract of Rhodopseudomonas capsulata. Biotechnol. Prog 2008, 24, 476-480.

(9) Klaus, T.; Joerger, R.; Olsson, E.; Granqvist, C.-G.: Silver-based crystalline nanoparticles, microbially fabricated. PNAS 1999, 96, 13611-13614.

(10) Parikh, R. Y.; Singh, S.; Prasad, B. L.; Patole, M. S.; Sastry, M.; Shouche, Y. S.: Extracellular Synthesis of Crystalline Silver Nanoparticles and Molecular Evidence of Silver Resistance from Morganella sp.: towards Understanding Biochemical Synthesis Mechanism. Chembiochem : $a$ European journal of chemical biology 2008, 9, 1415-1422.

(11) Kalimuthu, K.; Suresh Babu, R.; Venkataraman, D.; Bilal, M.; Gurunathan, S.: Biosynthesis of Silver Nanocrystals by Bacillus licheniformis. Colloids and Surfaces B: Biointerfaces 2008, 65, 150-153.

(12) Coker, V. S.; Bennett, J. A.; Telling, N. D.; Henkel, T.; Charnock, J. M.; van der Laan, G.; Pattrick, R. A. D.; Pearce, C. I.; Cutting, R. S.; Shannon, I. J.; Wood, J.; Arenholz, E.; Lyon, I. C.; Lloyd, J. R.: Microbial Engineering of Nanoheterostructures: Biological Synthesis of a Magnetically Recoverable Palladium Nanocatalyst. ACS Nano 2010, 4, 2577-2584.

(13) Konishi, Y.; Ohno, K.; Saitoh, N.; Nomura, T.; Nagamine, S.; Hishida, H.; Takahashi, Y.; Uruga, T.: Bioreductive Deposition of Platinum Nanoparticles on the Bacterium Shewanella algae. Journal of biotechnology 2007, 128, 648-653.

(14) Riddin, T. L.; Govender, Y.; Gericke, M.; Whiteley, C. G.: Two Different Hydrogenase Enzymes from Sulphate-reducing Bacteria Are Responsible for the Bioreductive Mechanism of Platinum into Nanoparticles. Enzyme and Microbial Technology 2009, 45, 267-273.

(15) Nair, B.; Pradeep, T.: Coalescence of Nanoclusters and Formation of Submicron Crystallites Assisted by Lactobacillus Strains. Crystal Growth \& Design 2002, 2, 293-298.

(16) Lovley, D. R.; Stolz, J. F.; Nord, G. L. J.; Phillips, E. J. P.: Anaerobic Production of Magnetic by a Dissimilatory Iron-reducing Microorganism. Nature 1987, 330, 252-254.

(17) Bazylnski, D. A.; Frankel, R. B.; Heywood, B. R.; Mann, S.; King, J. W.; Donaghay, P. L.; Hanson, A. K.: Controlled Biomineralization of Magnetite $\left(\mathrm{Fe}_{3} \mathrm{O}_{4}\right)$ and Greigite $\left(\mathrm{Fe}_{3} \mathrm{~S}_{4}\right)$ in a Magnetotactic Bacterium. Applied and environmental microbiology 1995, 61, 3232-3239.

(18) Jha, A. K.; Prasad, K.; Kulkarni, A. R.: Synthesis of $\mathrm{TiO}_{2}$ Nanoparticles Using Microorganisms. Colloids and Surfaces B: Biointerfaces 2009, 71, 226-229. 
(19) Prasad, K.; Jha, A. K.: ZnO Nanoparticles: Synthesis and Adsorption Study. Natural Science 2009, 01, 129-135.

(20) Sweeney, R. Y.; Mao, C.; Gao, X.; Burt, J. L.; Belcher, A. M.; Georgiou, G.; Iverson, B. L.: Bacterial Biosynthesis of Cadmium Sulfide Nanocrystals. Chemistry \& biology 2004, 11, 1553-1559.

(21) Bai, H. J.; Zhang, Z. M.; Guo, Y.; Yang, G. E.: Biosynthesis of Cadmium Sulfide Nanoparticles by Photosynthetic Bacteria Rhodopseudomonas palustris. Colloids and Surfaces B: Biointerfaces 2009, 70, 142-146.

(22) Kowshik, M.; Deshmukh, N.; Vogel, W.; Urban, J.; Kulkarni, S. K.; Paknikar, K. M.: Microbial Synthesis of Semiconducteur CdS Nanoparticles, Their Characterization, and Their Use in The Fabrication in an Ideal Diode. Biotechnology and bioengineering 2002, 78, 583-588.

(23) Gong, J.; Zhang, Z. M.; Bai, H. J.; Yang, G. E.: Microbiological Synthesis of Nanophase $\mathrm{PbS}$ by Desulfotomaculum sp. Science in China Series E: Technological Sciences 2007, 50, 302-307.

(24) Pearce, C. I.; Coker, V. S.; Charnock, J. M.; Pattrick, R. A.; Mosselmans, J. F.; Law, N.; Beveridge, T. J.; Lloyd, J. R.: Microbial Manufacture of Chalcogenide-based Nanoparticles via the Reduction of Selenite using Veillonella atypica: an in situ EXAFS Study. Nanotechnology 2008, 19, 155603 (13pp).

(25) J.H. Lee; M.G. Kim; B. Yoo; Myung, N. V.; Maeng, J.; Lee, T.; Dohnalkova, A. C.; Fredrickson, J. K.; Sadowsky, M. J.; Hur, H. G.: Biogenic Formation of Photoactive Arsenic-sulfide Nanotubes by Shewanella sp. Strain HN-41. PNAS 2007, 104, 20410-20415.

(26) Mukherjee, P.; Ahmad, A.; Mandal, D.; Senapati, S.; Sainkar, S. R.; Khan, M. I.; Ramani, R.; Parischa, R.; Ajayakumar, P. V.; Alam, M.; Sastry, M.; Kumar, R.: Bioreduction of $\mathrm{AuCl}_{4}$ Ions by the Fungus Verticillium sp. and Surface Trapping of the Gold Nanoparticles Formed. Angew. Chem. Int. Ed. 2001, 40, 3585-3588.

(27) Mukherjee, P.; Senapati, S.; Mandal, D.; Ahmad, A.; Khan, M. I.; Kumar, R.; Sastry, M.: Extracellular Synthesis of Gold Nanoparticles by the Fungus Fusarium oxysporum. Chembiochem : $a$ European journal of chemical biology 2002, 5, 461-463.

(28) Pimprikar, P. S.; Joshi, S. S.; Kumar, A. R.; Zinjarde, S. S.; Kulkarni, S. K.: Influence of Biomass and Gold Salt Concentration on Nanoparticle Synthesis by the Tropical Marine Yeast Yarrowia lipolytica NCIM 3589. Colloids and Surfaces B: Biointerfaces 2009, 74, 309-316.

(29) Mukherjee, P.; Ahmad, A.; Mandal, D.; Senapati, S.; Sainkar, S. R.; Khan, M. I.; Parishcha, R.; Ajaykumar, P. V.; Alam, M.; Kumar, R.; Sastry, M.: Fungus-Mediated Synthesis of Silver Nanoparticles and Their Immobilization in the Mycelial Matrix: A Novel Biological Approach to Nanoparticle Synthesis. Nano Letters 2001, 1, 515-519.

(30) Duran, N.; Marcato, P. D.; Alves, O. L.; Souza, G. I.; Esposito, E.: Mechanistic Aspects of Biosynthesis of Silver Nanoparticles by Several Fusarium oxysporum Strains. Journal of nanobiotechnology 2005, 3, 1-7.

(31) Kowshik, M.; Ashtaputre, S.; Kharrazi, S.; Vogel, W.; Urban, J.; Kulkarni, S. K.; Paknikar, K. M.: Extracellular Synthesis of Silver Nanoparticles by a Silver-tolerant Yeast Strain MKY3. Nanotechnology 2003, 14, 95-100.

(32) Bharde, A.; Rautaray, D.; Bansal, V.; Ahmad, A.; Sarkar, I.; Yusuf, S. M.; Sanyal, M.; Sastry, M.: Extracellular Biosynthesis of Magnetite using Fungi. Small 2006, 2, 135-141.

(33) Bansal, V.; Rautaray, D.; Ahmad, A.; Sastry, M.: Biosynthesis of Zirconia Nanoparticles using the Fungus Fusarium oxysporum. Journal of Materials Chemistry 2004, 14, 3303-3305.

(34) Bansal, V.; Poddar, P.; Ahmad, A.; Sastry, M.: Room-Temperature Biosynthesis of Ferroelectric Barium Titanate Nanoparticles. JACS 2006, 128, 11958-11963.

(35) Jha, A. K.; Prasad, K.; Prasad, K.: A Green Low-cost Biosynthesis of $\mathrm{Sb}_{2} \mathrm{O}_{3}$ Nanoparticles. Biochemical Engineering Journal 2009, 43, 303-306.

(36) Bansal, V.; Rautaray, D.; Bharde, A.; Ahire, K.; Sanyal, A.; Ahmad, A.; Sastry, M.: Fungus-mediated Biosynthesis of Silica and Titania Particles. Journal of Materials Chemistry 2005, 15, 2583-2589.

(37) Sanghi, R.; Verma, P.: A Facile Green Extracellular Biosynthesis of CdS Nanoparticles by Immobilized Fungus. Chemical Engineering Journal 2009, 155, 886-891. 
(38) Ahmad, A.; Mukherjee, P.; Mandal, D.; Senapati, S.; Khan, M. I.; Kumar, R.; Sastry, M.: Enzyme Mediated Extracellular Synthesis of CdS Nanoparticles by the Fungus, Fusarium oxysporum. J. AM. CHEM. SOC. 2002, 124, 12108-12109.

(39) Krumov, N.; Oder, S.; Perner-Nochta, I.; Angelov, A.; Posten, C.: Accumulation of CdS Nanoparticles by Yeasts in a Fed-batch Bioprocess. Journal of biotechnology 2007, 132, 481-486.

(40) Williams, P.; Keshavarz-Moore, E.; Dunnill, P.: Efficient Production of Microbially Synthesized Cadmium Sulfide Quantum semiconductor crystallites. Enzyme and Microbial Technology 1996, 19, 208-213.

(41) Kumar, S. A.; Ansary, A. A.; Ahmad, A.; Khan, M. I.: Extracellular Biosynthesis of CdSe Quantum Dots by the Fungus Fusarium oxysporum. Journal of Biomedical Nanotechnology 2007, 3, 190-194.

(42) Mata, Y. N.; Torres, E.; Blazquez, M. L.; Ballester, A.; Gonzalez, F.; Munoz, J. A.: Gold(III) Biosorption and Bioreduction with the Brown Alga Fucus vesiculosus. Journal of hazardous materials 2009, 166, 612-618.

(43) Singaravelu, G.; Arockiamary, J. S.; Kumar, V. G.; Govindaraju, K.: A Novel Extracellular Synthesis of Monodisperse Gold Nanoparticles using Marine alga, Sargassum wightii Greville. Colloids and Surfaces B: Biointerfaces 2007, 57, 97-101.

(44) Arockiya Aarthi Rajathi, F.; Parthiban, C.; Ganesh Kumar, V.; Anantharaman, P.: Biosynthesis of Antibacterial Gold Nanoparticles Using Brown Alga, Stoechospermum marginatum (kutzing). Spectrochimica Acta Part A: Molecular and Biomolecular Spectroscopy 2012, 99, 166-173.

(45) Liu, B.; Xie, J.; Lee, J. Y.; Ting, Y. P.; Chen, J. P.: Optimization of High-Yield Biological Synthesis of Single-Crystalline Gold Nanoplates. J Phys Chem C 2005, 109, 15256-15263.

(46) Greene, B.; Hosea, M.; McPherson, R.; Henzl, M.; Alexander, M. D.; Darnall, D. W.: Interaction of Gold(I) and Gold(III) Complexes with Algal Biomass. Environmental science \& technology 1986, 20, 627-632.

(47) Senapati, S.; Syed, A.; Moeez, S.; Kumar, A.; Ahmad, A.: Intracellular Synthesis of Gold Nanoparticles Using Alga Tetraselmis kochinensis. Materials Letters 2012, 79, 116-118.

(48) Chakraborty, N.; Banerjee, A.; Lahiri, S.; Panda, A.; Ghosh, A. N.; Pal, R.: Biorecovery of Gold using Cyanobacteria and an Eukaryotic Alga with Special Reference to Nanogold Formation a Novel Phenomenon. Journal of Applied Phycology 2008, 21, 145-152.

(49) Parial, D.; Patra, H. K.; Roychoudhury, P.; Dasgupta, A. K.; Pal, R.: Gold Nanorod Production by Cyanobacteria - A Green Chemistry Approach. Journal of Applied Phycology 2011, 24, 55-60.

(50) Lengke, M. F.; Fleet, M. E.; Southam, G.: Morphology of Gold Nanoparticles Synthesized by Filamentous Cyanobacteria from Gold(I)-Thiosulfate and Gold(III)-Chloride Complexes. Langmuir : the ACS journal of surfaces and colloids 2006, 22, 2780-2787.

(51) Lengke, M. F.; Fleet, M. E.; Southam, G.: Synthesis of Platinum Nanoparticles by Reaction of Filamentous Cyanobacteria with Platinum(IV)-Chloride Complex. Langmuir : the ACS journal of surfaces and colloids 2006, 22, 7318-7323.

(52) Lengke, M. F.; Fleet, M. E.; Southam, G.: Biosynthesis of Silver Nanoparticles by Filamentous Cyanobacteria from a Silver(I) Nitrate Complex. Langmuir : the ACS journal of surfaces and colloids 2007, 23, 2694-2699.

(53) Lengke, M. F.; Fleet, M. E.; Southam, G.: Synthesis of Palladium Nanoparticles by Reaction of Filamentous Cyanobacterial Biomass with a Palladium(II) Chloride Complex. Langmuir : the ACS journal of surfaces and colloids 2007, 23, 8982-8987.

(54) Brayner, R.; Barberousse, H.; Hemadi, M.; Djédjat, C.; Yeprémian, C.; Coradin, T.; Livage, J.; Fiévet, F.; A., C.: Cyanobacteria as Bioreactors for the Synthesis of $\mathrm{Au}, \mathrm{Ag}, \mathrm{Pd}$, and Pt Nanoparticles via an Enzyme-Mediated Route. Journal of Nanoscience and Nanotechnology 2007, 7, 2696-2708.

(55) Schröfel, A.; Kratošová, G.; Bohunická, M.; Dobročka, E.; Vávra, I.: Biosynthesis of Gold Nanoparticles Using Diatoms - Silica-Gold and EPS-Gold Bionanocomposite Formation. Journal of Nanoparticle Research 2011, 13, 3207-3216. 
(56) Luangpipat, T.; Beattie, I. R.; Chisti, Y.; Haverkamp, R. G.: Gold Nanoparticles Produced in a Microalga. Journal of Nanoparticle Research 2011, 13, 6439-6445.

(57) Dahoumane, S. A.; Djédiat, C.; Yeprémian, C.; Couté, A.; Fiévet, F.; Coradin, T.; Brayner, R.: Species Selection for the Design of Gold Nanobioreactor by Photosynthetic Organisms. Journal of Nanoparticle Research 2012, 14, 883(17pp).

(58) Sicard, C.; Brayner, R.; Margueritat, J.; Hémadi, M.; Couté, A.; Yéprémian, C.; Djédiat, C.; Aubard, J.; Fiévet, F.; Livage, J.; Coradin, T.: Nano-gold Biosynthesis by Silica-encapsulated Microalgae: A "living" Bio-hybrid Material. Journal of Materials Chemistry 2010, 20, 9342-9347.

(59) Dahoumane, S. A.; Djédiat, C.; Yeprémian, C.; Couté, A.; Fiévet, F.; Coradin, T.; Brayner, R.: Recycling and Adaptation of Klebsormidium flaccidum Microalgae for the Sustained Production of Gold Nanoparticles. Biotechnology and bioengineering 2012, 109, 284-288.

(60) Dahoumane, S. A.; Wijesekera, K.; Filipe, C. D.; Brennan, J. D.: Stoichiometrically Controlled Production of Bimetallic Gold-Silver Alloy Colloids Using Micro-alga Cultures. Journal of colloid and interface science 2014, 416, 67-72.

(61) Shabnam, N.; Pardha-Saradhi, P.: Photosynthetic Electron Transport System Promotes Synthesis of Au-Nanoparticles. PLOS ONE 2013, 8, e71123(7pp).

(62) Bertocchi, C.; Navarini, L.; Cesaro, A.; Anastasio, M.: Polysaccharides from Cyanobacteria. Carbohydr. Polymers 1990, 12, 127-153.

(63) Ninfa, A. J.; Ballou, D. P.; Benore, M.: Fundamental Laboratory Approches for Biochemistry and Biotechnology, 2nd Edition; John Wiley \& Sons Inc., 2010.

(64) Zhang, Y. X.; Zheng, J.; Gao, G.; Kong, Y. F.; Zhi, X.; Wang, K.; Zhang, X. Q.; D.X., C.: Biosynthesis of Gold Nanoparticles Using Chloroplasts. International journal of nanomedicine 2011, 6, 2899-2906.

(65) Brayner, R.; Coradin, T.; Beaunier, P.; Grenèche, J. M.; Djédiat, C.; Yeprémian, C.; Couté, A.; F., F.: Intracellular Biosynthesis of Superparamagnetic 2-lines Ferri-hydrite Nanoparticles Using Euglena gracilis Microalgae. Colloids and Surfaces B: Biointerfaces 2012, 93, 20-3.

(66) Brayner, R.; Yeprémian, C.; Djédiat, C.; Coradin, T.; Herbst, F.; Livage, J.; Fiévet, F.; A., C.: Photosynthetic Microorganism-mediated Synthesis of Akaganeite (beta-FeOOH) Nanorods. Langmuir : the ACS journal of surfaces and colloids 2009, 25, 10062-10067.

(67) Dahoumane, S. A.; Djédiat, C.; Yeprémian, C.; Couté, A.; Fiévet, F.; Brayner, R.: Design of Magnetic Akaganeite-Cyanobacteria Hybrid Biofilms. Thin Solid Films 2010, 518, 5432-5436. 